AGH DRILLING, OIL, GAS • Vol. 30 • No. $1 \cdot 2013$

http://dx.doi.org/10.7494/drill.2013.30.1.297

\author{
Paul F. Ziemkiewicz*
}

\title{
CHARACTERIZATION OF LIQUID WASTE STREAMS FROM SHALE GAS DEVELOPMENT
}

\section{PROJECT OVERVIEW}

Although hydraulic fracturing is not a new technique, its rapid deployment in the Marcellus Shale Formation has caused concern regarding the potential risks to human health and the environment. In order to better understand risks associated with shale gas development, the West Virginia Legislature in May 2012 requested the West Virginia University Water Research Institute to investigate the health implications of liquid wastes related to horizontal drilling and completion activities. The project focused on wastes generated during drilling to initiation of gas production. Literature reviews were conducted and followed by direct field monitoring. This overview addresses the liquid waste streams that are returned to the surface as flowback. It does not include post production liquids or the potential for human exposure via fluid movement from the fracturing zone upwards toward drinking water supplies.

\section{Water and Waste Stream Study}

The nomenclature for hydraulic fracturing wastewaters is not standardized across the industry. For the purposes of this study hydraulic fracturing fluids refer to the fluids injected with proppant in order to generate sufficient pressure to create fractures within the target formation. The term flowback refers to all fluids that return to the wellhead after hydraulic fracturing and prior to gas production. This includes hydraulic fracturing fluids, gases, gas liquids and water. Produced water consists of fluids that return to the wellhead subsequent to gas production. Within the first two years after well completion between 10 and $30 \%$ of the injected fluid returns to the surface as flowback or produced water. As the well is drilled,

* West Virginia Water Research Institute West Virginia University 
muds are used to cool the drill bit, control well pressures and lift rock cuttings to the surface. Cuttings and muds are separated at the surface where muds are typically recycled. Spent drilling muds and cuttings are removed for disposal. This study focuses on the characterization of flowback and produced water.

A literature review was conducted to characterize the water and waste streams associated with the development of horizontal shale gas wells including commonly used hydraulic fracturing fluids. The literature review was used to identify critical chemical parameters and to develop the well site water monitoring plan. The plan was updated as active well sites were monitored and study design and sampling methods were adapted to field conditions.

The field study focused on sampling and chemical analysis of hydraulic fracturing fluids and flowback waters of working hydraulic fracturing sites in the Marcellus Formation in West Virginia. The analytical parameters included both primary and secondary drinking water contaminants. Contaminants were evaluated based on exceedance of maximum contaminant levels as identified under the USEPA Safe Drinking Water Act (SDWA).

\section{LITERATURE REVIEW}

\section{Water and Waste Streams Associated with Horizontal Gas Well Development}

In 2008, several companies volunteered to participate in a study to characterize injected and flowback waters associated with completions of Marcellus shale gas wells (1). Nineteen well sites were identified throughout Pennsylvania and West Virginia where hydraulic fracturing was planned. Samples were taken of the supply (makeup) water prior to blending of additives, influent water (hydraulic fracturing fluid) following blending with additives but before the addition of sand, flowback samples at varying intervals after hydraulic fracturing, and water from each producing well 90 days after completion.

Influent water usually contains moderate to low concentrations of salts (Tab. 1). Total dissolved solids (TDS) in flowback increased with time while the flow rate decreased. Samples showing moderate TDS values in the influent water indicate that the makeup water consisted of some proportion of recycled flowback water. Oil and grease, and total organic carbon (TOC) concentrations in these samples indicate blending of flowback water with freshwater. Typically the dissolved solids in flowback and produced waters from Marcellus wells consisted of sodium, chloride, calcium and to a lesser extent, strontium, barium and bromide. Trace metals of toxicological concern were present at low levels. Nearly $96 \%$ of organic compounds were at concentrations below the detection level while $0.5 \%$ exceeded $1 \mathrm{mg} / \mathrm{L}$. Constituents in produced waters that exceeded $100 \mu \mathrm{g} / \mathrm{L}$ included components commonly present in produced waters from natural gas operations: benzene, toluene, ethylbenzene and xylene (BTEX); naphthalene; several methylated benzene compounds and an alkylated toluene. However, few determinations of these compounds exceeded $2 \mathrm{mg} / \mathrm{L}$ (1). Nearly all halogenated organic compounds were below the method detection limit. 
Table 1

Chemical characteristics of influent and flowback waters (1)

\begin{tabular}{|c|c|c|c|c|c|}
\hline Parameter & Units & $\begin{array}{l}\text { Influent } \\
\text { Water } \\
\text { Before } \\
\text { Additives }\end{array}$ & $\begin{array}{c}\text { Influent } \\
\text { Water After } \\
\text { Additives }\end{array}$ & $\begin{array}{c}\text { Flowback } \\
\text { Water } \\
5 \text { Days Out }\end{array}$ & $\begin{array}{c}\text { Flowback } \\
\text { Water } \\
14 \text { Days Out }\end{array}$ \\
\hline $\mathrm{pH}$ & No units & $6.7-7.4$ & $5.2-8.9$ & $5.8-7.2$ & $4.9-6.8$ \\
\hline Acidity & $\mathrm{mg} / \mathrm{L}$ & $<5-5.5$ & $<5-1230$ & $<5-447$ & $<5-473$ \\
\hline Total Alkalinity & $\mathrm{mg} / \mathrm{L}$ & $6.2-88.8$ & $5-308$ & $48.8-327$ & $26.1-121$ \\
\hline Hardness as $\mathrm{CaCO}_{3}$ & $\mathrm{mg} / \mathrm{L}$ & $18-1,080$ & $26-9,500$ & $5,100-55,000$ & $630-95,000$ \\
\hline TSS & $\mathrm{mg} / \mathrm{L}$ & $<2-24$ & $4-5290$ & $10.8-3220$ & $17-1,150$ \\
\hline Turbidity & NTU & $1.3-33.7$ & $2.7-715$ & $2.3-1,540$ & $10.5-1,090$ \\
\hline Chloride & $\mathrm{mg} / \mathrm{L}$ & $4.1-3,000$ & $18-10,700$ & $26,400-148,000$ & $1,670-181,000$ \\
\hline $\begin{array}{l}\text { Total Dissolved } \\
\text { Solids }\end{array}$ & $\mathrm{mg} / \mathrm{L}$ & $35-5,510$ & $221-27,800$ & $38,500-238,000$ & $3,010-261,000$ \\
\hline Specific Conductance & $\begin{array}{c}\mu \mathrm{mhos} / \mathrm{c} \\
\mathrm{m}\end{array}$ & $55-10,100$ & $177-34,600$ & $79,500-470,000$ & $6,800-710,000$ \\
\hline $\begin{array}{l}\text { Total Kjeldahl } \\
\text { Nitrogen }\end{array}$ & $\mathrm{mg} / \mathrm{L}$ & $<3-56.4$ & $2.3-400$ & 38-204 & $5.6-261$ \\
\hline Ammonia Nitrogen & $\mathrm{mg} / \mathrm{L}$ & $0.017-20.8$ & $0.28-441$ & 29.4-199 & $3.7-359$ \\
\hline Nitrate-Nitrite & $\mathrm{mg} / \mathrm{L}$ & $<0.1-3.0$ & $0.1-3.1$ & $<0.1-1.2$ & $<0.1-0.92$ \\
\hline Nitrite as $\mathrm{N}$ & $\mathrm{mg} / \mathrm{L}$ & $<0.05-4.9$ & $<0.05-5$ & $1.2-29.3$ & $<2.5-77.4$ \\
\hline $\begin{array}{l}\text { Biochemical Oxygen } \\
\text { Demand }\end{array}$ & $\mathrm{mg} / \mathrm{L}$ & $<2.0-110$ & $<2.0-2,220^{*}$ & $37.1-1,950$ & $2.8-2,070$ \\
\hline $\begin{array}{l}\text { Chemical Oxygen } \\
\text { Demand }\end{array}$ & $\mathrm{mg} / \mathrm{L}$ & $<10-924$ & $35.3-47,400$ & $195-17,700$ & $228-21,900$ \\
\hline Total Organic Carbon & $\mathrm{mg} / \mathrm{L}$ & 1.8-202 & $5.6-1,260$ & $3.7-388$ & $1.2-509$ \\
\hline $\begin{array}{l}\text { Dissolved Organic } \\
\text { Carbon }\end{array}$ & $\mathrm{mg} / \mathrm{L}$ & $1.4-222$ & $5-1,270$ & $30.7-501$ & $5-695$ \\
\hline Oil \& Grease & $\mathrm{mg} / \mathrm{L}$ & Not detected & $4.6-255$ & $4.6-655$ & $<4.6-103$ \\
\hline Cyanide, Total & $\mu \mathrm{g} / \mathrm{L}$ & $<10-625$ & $3.5-954$ & $<10-72.1$ & $<10$ \\
\hline Amenable Cyanide & $\mathrm{mg} / \mathrm{L}$ & $<0.01-0.27$ & $<0.01-0.87$ & $<0.01-0.032$ & $<0.01$ \\
\hline Bromide & $\mathrm{mg} / \mathrm{L}$ & $<0.2-31.9$ & $<0.2-107$ & $185-1,190$ & $15.8-1,600$ \\
\hline Fluoride & $\mathrm{mg} / \mathrm{L}$ & $<0.05-1.2$ & $<0.05-58.3$ & $<0.05-17.3$ & $<0.05-<50$ \\
\hline Total Sulfide & $\mathrm{mg} / \mathrm{L}$ & $1.6-5.6$ & $<3-8.8$ & $<3-5.6$ & $<3.0-3.2$ \\
\hline Sulfate & $\mathrm{mg} / \mathrm{L}$ & $3.8-139$ & $2.9-2,920$ & $2.4-106$ & $<10-89.3$ \\
\hline Total Phosphorus & $\mathrm{mg} / \mathrm{L}$ & $<0.1-0.14$ & $<0.1-16$ & $<0.01-2.5$ & $<0.1-2.2$ \\
\hline $\begin{array}{l}\text { Total Recoverable } \\
\text { Phenolics }\end{array}$ & $\mathrm{mg} / \mathrm{L}$ & $0.01-0.031$ & $<0.01-0.77$ & $<0.01-0.31$ & $<0.01-0.31$ \\
\hline Sulfite & $\mathrm{mg} / \mathrm{L}$ & $6-21.6$ & $<5-61.6$ & $2.5-38$ & $7.2-73.6$ \\
\hline $\begin{array}{l}\text { Methylene Blue Active } \\
\text { Substances (MBAS) }\end{array}$ & $\mathrm{mg} / \mathrm{L}$ & $<0.05-0.962$ & $<0.03-0.506$ & $<0.012-1.52$ & $<0.05-4.6$ \\
\hline
\end{tabular}




\section{Hydraulic Fracturing and Fracturing Fluids}

After a well is drilled and casing has been placed, the completion, or hydraulic fracturing stage, begins (2). Hydraulic fracturing was first developed in the 1940s to stimulate production from oil reservoirs with declining productivity (3). In the production zone of the well, a perforation gun shoots holes through the casing and cement at pre-determined locations (4). Within a horizontal section, hydraulic fracturing takes place in multiple stages where fluids are pumped through the perforations. The process is repeated until the length of the production zone has been fractured. Hydraulic fracturing takes place under high pressure (approximately 60,000 $\mathrm{kPa}$ ) to create microfractures in the rock formation and allow the gas to be extracted. The sand or other proppant holds the new fractures open allowing the gas to flow freely out of the formation and into a production well for compression, transmission and sale.

Hydraulic fracturing fluid consists of water, sand and other ingredients including friction reducers (slickwater), corrosion inhibitors, oxygen scavengers, scale inhibitors and biocides (disinfectants; 5). The Hydraulic fracturing fluid is typically formulated at the well site. The water and sand typically make up $98 \%$ to $99 \%$ of the hydraulic fracturing fluid with the rest consisting of the various chemical additives used to improve the effectiveness of the fracture and subsequent release of natural gas. Nearly all fluids currently used in Marcellus Shale hydraulic fracturing operations are water based or mixed slickwater fracturing fluids (6).

Hydraulic fracturing fluids have been found to contain hydrochloric acid, petroleum distillate, ammonium bisulfate, fluorocarbons, naphthalene, butanol, and formaldehyde (7). Many of these chemicals are either carcinogenic or can cause a wide range of health problems affecting eyes, skin, lungs and the nervous system.

In 2010, the United States House of Representatives Committee on Energy and Commerce conducted an investigation into the practice of hydraulic fracturing in the United States (8). Fourteen leading oil and gas companies were asked to provide information on the types and volumes of hydraulic fracturing products used in their fluids between 2005 and 2009. The investigation yielded a total of 750 different chemicals and other components used by these companies to create their hydraulic fracturing fluids. Components were found to range from harmless (table salt and citric acid), to unexpected (instant coffee and walnut hulls), to extremely toxic (benzene and lead; 8). Methanol was found to be the most widely used chemical by the companies surveyed. Methanol is considered a hazardous air pollutant and is on the candidate list for potential regulation under the SDWA (8). Other commonly used chemicals included isopropyl alcohol (surfactant), 2-butoxyethanol (foaming agent or surfactant) and ethylene glycol (scale inhibitor) along with silicon dioxide (sand proppant). The Committee's investigation also found that the fourteen oil and gas companies surveyed used hydraulic fracturing products containing twenty-nine chemicals that are known as or may be possible human carcinogens regulated under the SDWA due to risks to human health, or listed as hazardous air pollutants under the Clean Air Act.

Companies develop specific fracturing fluid formulations which are generally proprietary (9). 


\section{Characteristics of Flowback Waters}

Once the hydraulic fracturing process is complete and the wellbore pressure released, a portion of the fracturing fluid flows back up the wellbore to the well head. This flowback is collected in tanks or lined pits and then either used as makeup water, treated or otherwise disposed of.

The Marcellus is considered a desiccated formation. It contains little if any water in most locations. So, flowback and produced water consist largely of the originally injected fluids plus compounds acquired during contact with the formation. These may include additives that were introduced during hydraulic fracturing as well as inclusions such as salts, oils and greases, metals and organic compounds, and naturally occurring radioactive materials (NORM). The primary radionuclides of concern are isotopes of radium that originate from the decay of uranium and thorium naturally present in the subsurface. Organic compounds are either separable with de-oiling technologies (such as oils and greases) or they are soluble (such as phenol, mono-carboxylic acids glycols), requiring a more complicated removal process (10).

\section{Radioactivity}

All environmental media contain some level of radioactivity or naturally occurring radioactive materials (NORM). There are three main groups of radioactive elements that exist in all soil and rock on earth: the uranium-238/radium-226 radionuclide series, the thorium-232 radionuclide series, and potassium-40 (11). Typical, natural background concentrations of uranium, radium, and thorium present in soil and rock in the eastern United States range from 0.5 to $1.0 \mathrm{pCi} / \mathrm{g}$ each and 10 to $30 \mathrm{pCi} / \mathrm{L}$ for potassium-40 (11). Certain commercial minerals, such as gypsum, zirconium and titanium used in paint and zircon sand and carborundum used in sandblasting and ceramics have radioactivity levels ranging from 5 to $50 \mathrm{pCi} / \mathrm{L}(12)$.

Industrial waste materials may contain higher than background levels of NORM or technologically enhanced naturally occurring radioactive materials (TENORM; 13). Exposure to naturally occurring radiation makes up the majority of an average person's yearly radiation dose and is generally not considered of significance to health and safety (14). Certain industries handle significant quantities of NORM, which can mainly be found in their waste streams. As potential hazards are identified, monitoring and regulation of such materials and activities have increased. Industries known to have NORM issues include: coal, oil and gas, metal mining and smelting, phosphate fertilizer industry, building and recycling (14).

In shale gas development, NORM can be found in drill cuttings, flowback waters and natural gas (15). NORM are more noticeable in areas where sediments or precipitates tend to accumulate such as equipment, pipes and storage tanks, and as a result, exposure may occur when repair work is performed (16). Dense steel used in natural gas production blocks alpha and beta radiation and greatly reduces transmission of gamma radiation. Distance also reduces exposure. So, risks to the general public are most likely when contaminated fluids mix with domestic water sources such as shallow groundwater and streams. 
Mishandling of contaminated pipes and storage tanks can cause worker and public exposure to NORMS (16). According to the World Nuclear Association, NORM in the oil and gas industry poses a problem to workers particularly during maintenance, waste transport and processing, and decommissioning (14). In particular, Lead-210 deposits and films are only a concern when pipe internals become exposed (14). External exposure due to NORM in the oil and gas industry is generally low enough not to require protective measures to ensure that workers stay beneath their annual dose limits and internal exposures can be minimized through hygiene practices (14).

Radioactivity in the Marcellus Shale varies across the formation. Over time, the radioactive isotopes decay with half-lives from a few days to several hundred years. Levels of NORM in Marcellus Shale flowback tend to be relatively low with higher concentrations in the later flowback waters and produced water. Alpha particles and Radium-226 in some produced waters in New York have been found at concentrations exceeding drinking water maximum contaminant levels of $15 \mathrm{pCi} / \mathrm{L}$ and $5 \mathrm{pCi} / \mathrm{L}$, respectively (12).

Exposure to radionuclides, even at low levels can raise serious health concerns. Radon gas, known to exist within the Marcellus has been shown to be a primary cause of lung cancer. The EPA has established drinking water guidelines for certain radionuclides: $5 \mathrm{pCi} / \mathrm{L}$ for radium, $30 \mathrm{pCi} / \mathrm{L}$ for uranium and $15 \mathrm{pCi} / \mathrm{L}$ for total alpha emitters. EPA has also set radium-226 levels in wastewater discharges at $60 \mathrm{pCi} / \mathrm{L}$, discharges to land surface at $5 \mathrm{pCi} / \mathrm{g}$ and $15 \mathrm{pCi} / \mathrm{g}$ to subsurface soils.

The New York Department of Health analyzed three samples of flowback waters from Marcellus wells and found elevated levels of gross alpha, gross beta, and radium-226, which is characteristic of Devonian-age shales (4). The presence of elevated radium-226 concentrations indicates particular attention to NORMS monitoring and treatment as well as caution when considering application of brines on roads for dust suppression or deicing (12). Based on these findings, the New York Department of Health recommended continued sampling of flowback waters and drilling muds and cuttings. Determination of gross alpha, beta and gamma activity was recommended. Although the accuracy of field measurement of gross alpha is uncertain in samples with high dissolved solids, it is an inexpensive screening tool, and if counts exceed $15 \mathrm{pCi} / \mathrm{L}$, additional analysis was determined to be warranted (12).

\section{METHODS}

\section{Well site sampling}

Active hydraulic fracturing wells in northern West Virginia were sampled to determine contaminant concentrations in hydraulic fracturing fluids and flowback.

The West Virginia Department of Environmental Protection (WVDEP) contacted natural gas developers and established access to Marcellus gas well sites for WVU researchers to collect water samples. Samples were collected and analyzed for a wide range of inorganic, organic and radioactive constituents to characterize the water and waste streams associated with the various stages of horizontal gas well development. 
Samples were sent to certified laboratories for analysis. It is important to note that all chemical determinations are for total as opposed to dissolved concentrations. Our analyses included the organic compounds benzene, toluene, ethyl benzene and xylene. All are subject to SDWA primary pollutant standards.

\section{FINDINGS}

In addition to characterization of flowback, study objectives included comparison of hydraulic fracturing fluids with flowback water.

\section{Comparison of hydraulic fracturing fluids and flowback}

Four freshwater (makeup water) samples, two hydraulic fracturing fluids and thirteen flowback samples were analyzed. Water quality of water and waste streams deteriorated during the flowback cycle. One of two hydraulic fracturing fluid samples exceeded the drinking water standard for benzene in measurable quantities while ten of thirteen flowback samples contained benzene in concentrations in excess of the primary drinking water standard of $5 \mu \mathrm{g} / \mathrm{L}$. Both hydraulic fracturing fluids, all of the drilling muds and flowback samples contained detectable TPH (diesel range). It is important to note, this determination, also known as diesel range organics (DRO) does not indicate that diesel is present. Rather, it indicates that hydrocarbons in the range of C11 to $\mathrm{C} 28$ are present. This could include diesel or common hydraulic fracturing fluid additives such as guar gum, an extract of the guar bean used to increase the viscosity of the hydraulic fracturing fluid to efficiently deliver the proppant into the formation. There was no correlation between concentrations of benzene and TPH (diesel range). Since diesel contains benzene this suggests that the measured diesel range organics were not, in fact, diesel fuel. All flowback samples contained high concentrations of inorganic ions including sodium, chloride, bromide and barium.

Three types of liquids used in the horizontal drilling and hydraulic fracturing processes were evaluated to determine if drinking water standards were exceeded: Makeup (MU) water consists of varying proportions of fresh water and recycled flowback water that is mixed with chemicals to make hydraulic fracturing fluids $(H F F)$ which are injected into the formation along with a proppant, and flowback $(F B)$ is the fluid which returns via the wellhead to the surface after hydraulic fracturing is complete.

All flowback samples exceeded drinking water standards for barium, chloride, iron, manganese, total dissolved solids and radium 226 (Tab. 2). Eighty-percent of flowback samples exceeded drinking water standards for gross alpha, beta and radium 228. The organic parameters benzene, toluene, methyl blue active surfactant (MBAS) and styrene exceeded drinking water standards at rates of $77,23,15$ and $8 \%$, respectively. Selenium exceeded the drinking water standard in $23 \%$ of flowback samples while chromium and lead exceeded their drinking water standards in $8 \%$ of the flowback samples. Overall, drinking water standards were exceeded for eighteen parameters in the flowback samples. 
Table 2

Exceedances of Drinking Water Standards

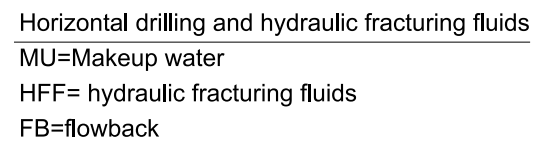

$\mathrm{FB}=$ flowback

\begin{tabular}{|c|c|c|}
\hline type & & $\begin{array}{c}\text { drinking } \\
\text { water std. }{ }^{*}\end{array}$ \\
\hline 1 & $\mathrm{Ba}$ & $a$ \\
\hline 1 & $\mathrm{Cl}$ & b \\
\hline 1 & $\mathrm{Fe}$ & b \\
\hline 1 & $\mathrm{Mn}$ & b \\
\hline 1 & TDS & $\mathrm{b}$ \\
\hline $\mathrm{R}$ & Radium-226 & a \\
\hline $\mathrm{R}$ & Gross Alpha & a \\
\hline $\mathrm{R}$ & Gross Beta & a \\
\hline $\mathrm{R}$ & Radium-228 & a \\
\hline 0 & Benzene & a \\
\hline I & $\mathrm{pH}$ & b \\
\hline I & $\mathrm{Al}$ & b \\
\hline I & $\mathrm{Se}$ & a \\
\hline 0 & Toluene & a \\
\hline 0 & MBAS & b \\
\hline 1 & $\mathrm{Cr}$ & a \\
\hline I & $\mathrm{Pb}$ & a \\
\hline O & Styrene & a \\
\hline I & As & a \\
\hline I & $\mathrm{Hg}$ & a \\
\hline 1 & Nitrate & a \\
\hline 1 & Nitrite & a \\
\hline 1 & $\mathrm{Ag}$ & b \\
\hline 1 & $\mathrm{SO} 4$ & b \\
\hline I & $\mathrm{Zn}$ & $\mathrm{b}$ \\
\hline 0 & Ethylbenze & a \\
\hline 0 & Xylene $(m, p)$ & a \\
\hline 0 & Xylene (o) & a \\
\hline $\mathrm{R}$ & Uranium-238 & a \\
\hline $\mathrm{R}$ & Uranium-238 & a \\
\hline
\end{tabular}

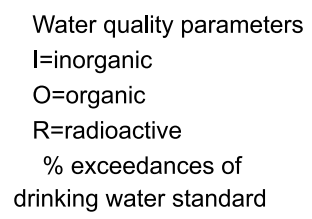

Six parameters in the hydraulic fracturing fluids exceeded drinking water standards. The hydraulic fracturing fluids in this case consisted of diluted flowback which may explain the presence of contaminants such as barium, chloride, iron, manganese and benzene albeit in lower concentrations than found in flowback. The results suggest that the high contaminant concentrations in flowback result from contaminants acquired while the hydraulic fracturing fluids are in contact with the Marcellus Formation.

Flowback from two wells, one in the dry section of the Marcellus Formation and another in the wet section were sampled during the flowback cycle beginning with the initial 
flowback (day zero) and then at days 7,14 and 35. The wet section of the field is characterized by higher production of natural gas liquids: ethane, propane and butane. Results are presented for selected inorganic (Tab. 1), organic (Tab. 2) and radioactive (Tab. 3) parameters. Radioactive determinations were made only on samples from the wet gas well. The results indicate that concentrations generally increased sharply by day seven, declined by day fourteen then increased again by day 35. Initial Inorganic concentrations were higher than organics in the initial flowback samples. The makeup water for the hydraulic fracturing fluid used at this well included recycled flowback which had been filtered to remove suspended solids. Whether this also removed organic components is uncertain. Concentrations of TDS, $\mathrm{Cl}, \mathrm{Br}$ and $\mathrm{Ba}$ were all much higher in the dry well while benzene, toluene and xylene were higher in the wet well. Radioactive parameters followed a temporal pattern that was nearly identical to the inorganic and organic parameters.
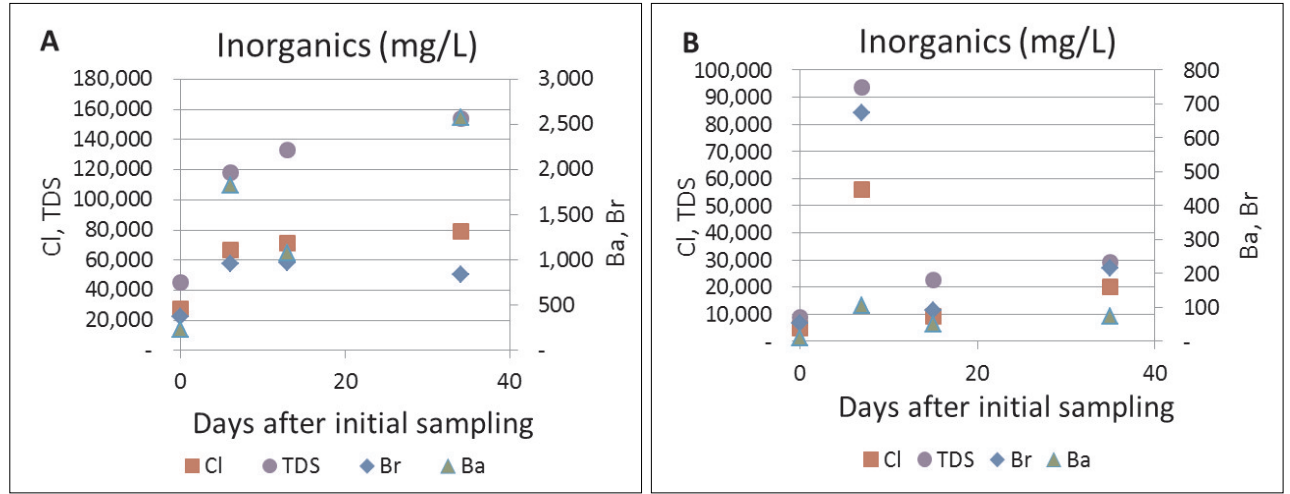

Fig. 1. The figures show the increase in major ions flowback sampled over a 35 day period at wells in the A dry gas field and $\mathbf{B}$ the wet gas field in central and western West Virginia respectively
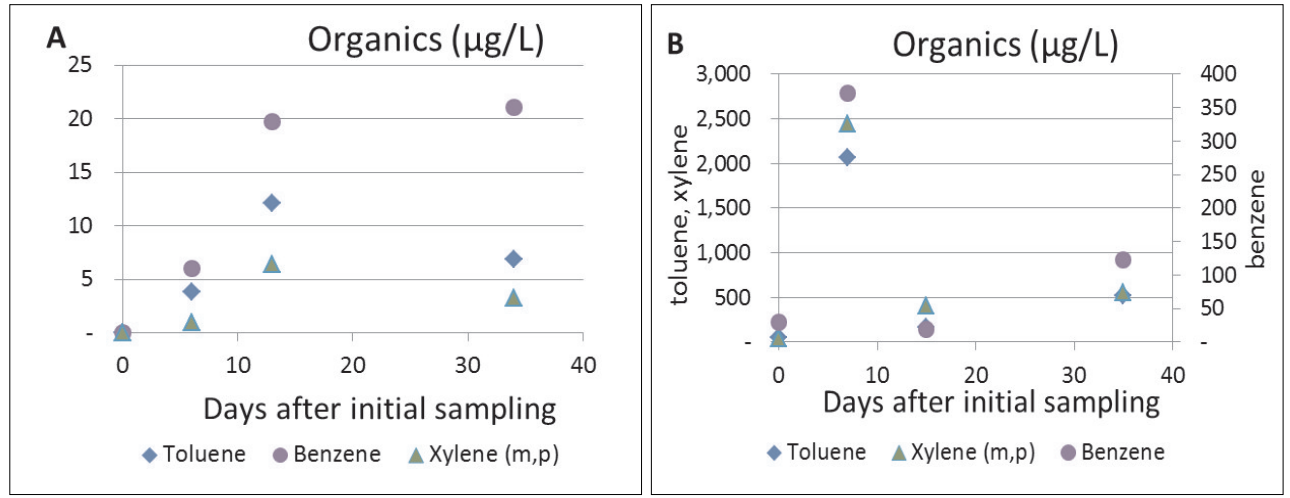

Fig. 2. The figures show the increase in selected organic compounds in flowback sampled over a 35 day period at wells in the $\mathbf{A}$ dry gas field and $\mathbf{B}$ the wet gas field in central and western West Virginia respectively 


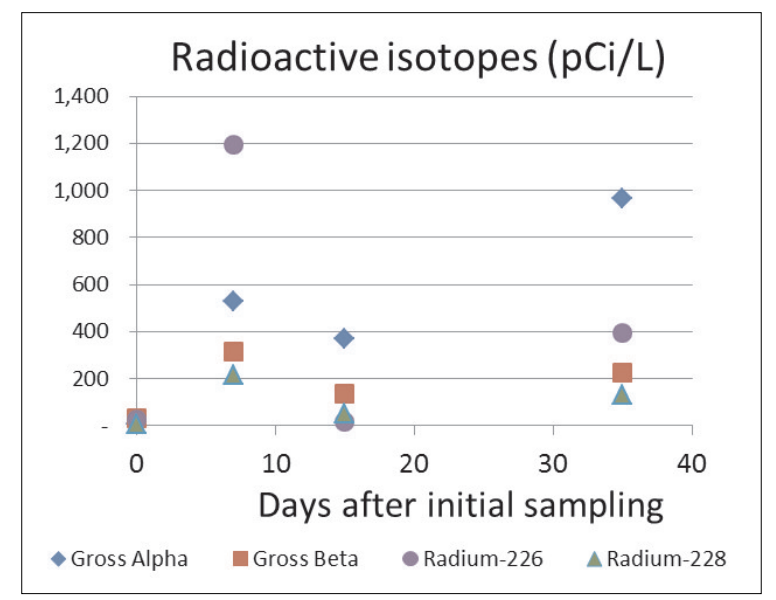

Fig. 3. The figure shows the increase in selected radioactive parameters in flowback sampled over a 35 day period at a well in the wet gas field in western West Virginia

Table 3

Groundwater Exposure to Shale Gas Waste Streams

\begin{tabular}{|l|c|c|c|c|}
\hline \multirow{2}{*}{ Material type } & \multirow{2}{*}{$\mathrm{n}$} & \multicolumn{3}{|c|}{ SDWA exceedences } \\
\cline { 3 - 5 } & & primary & secondary & radioactivity \\
\hline Hydrofractring fluid & 2 & $11 \%$ & $40 \%$ & ND \\
\hline Flowback & 13 & $18 \%$ & $47 \%$ & $85 \%$ \\
\hline \multicolumn{2}{|c|}{} & \multicolumn{3}{|c|}{ ND = not determined } \\
\cline { 3 - 5 }
\end{tabular}

\section{Identification of Potential Health Concerns}

Flowback and hydraulic fracturing fluids both exceeded SDWA limits to varying degrees. The extent to which they are properly and safely handled will determine the degree of human exposure via drinking water. An attempt to prioritize the potential for human exposure via groundwater contamination is reflected in Table 3. Note, only two hydraulic fracturing fluids were analyzed and no radioactivity determinations were conducted on those samples.

Table 3 does not reflect the much higher contaminant concentrations in flowback. Nonetheless, flowback yields the highest exposure risk since it is a liquid, it is transported off-site, it has multiple toxicities and it is produced in high volumes. Hydraulic fracturing fluids are usually prepared on-site, minimizing transportation risk. It may be spilled on the drill pad due to an accident or during a blowout. However, proper lining and containment on-site would minimize exposure to groundwater. Both flowback and hydraulic fracturing fluids may escape the wellbore if it is not properly installed and cemented. The risk of migration of these fluids from the target formation to drinking water, considering the distan- 
ce is remote but not absent. Care must be taken to avoid faults and old gas wells that may conduct these fluids to potable aquifers.

Practices that prevent environmental and human health exposures are critical. The following are recommended:

- Ensure the integrity of the handling chain for each of the waste streams, identify the weak points and focus the inspectors' attention on those areas.

- Ensure the integrity of wellbores and cement.

The liquid wastes generated during shale gas drilling and well completion can be contained and disposed of in a manner that protects human health and the environment. Problems occur when leakage occurs. Leakage points include:

Hydraulic fracturing fluid

- Spillage prior to injection.

- Blowout during hydraulic fracturing.

Flowback

- The well bore.

- Blowout during hydraulic fracturing.

- Impoundment failure.

- Impoundment leakage.

- Fluid spillage at the well site.

- Improper disposal.

Major types of waste, cause of release and control mechanisms are summarized in Table 4 .

Table 4

Control Options for Potential Releases

cause of release

control

\begin{tabular}{|c|c|}
\hline \multicolumn{2}{|l|}{ Hydraulic fracturing fluid: } \\
\hline Spillage prior to injection & Containment for 1 stage volume on drill pad \\
\hline Blowout during fracking & Primary and backup BOPs \\
\hline \multicolumn{2}{|l|}{ Flowback } \\
\hline Leakage in the well bore & Well integrity test prior to hydraulic fracturing \\
\hline Blowout after fracking & Primary and backup BOPs \\
\hline Impundment failure & Follow WVDEP Impoundment Guidelines \\
\hline Impoundment leakage & Use double polymer liner for pits and impoundments \\
\hline Fluid spillage at the well site & Containment for 1 stage volume on drill pad \\
\hline Improper disposal & Enforceable disposal plan \\
\hline \multicolumn{2}{|l|}{ Drilling muds and cuttings } \\
\hline Storage pit leakage & Use double polymer liner for pits and impoundments \\
\hline fluid spillage at the well site & Containment for 1 stage volume on drill pad \\
\hline Improper disposal & Enforceable disposal plan \\
\hline
\end{tabular}




\section{RECOMMENDATIONS TO CONTROL ACCIDENTAL, TOXIC RELEASE}

The potential for release of hazardous fluids and solids from drilling and completion operations involves a limited number of substances and release points. A five point release control program that would address the major risks that would affect drinking water is recommended. The following list of control measures should be considered for further refinement:

1. On-site containment. A single horizontal well is typically completed with ten hydraulic fracturing stages. A hydraulic fracturing stage includes about one tenth of the typical hydraulic fracturing fluid volume of $19,000 \mathrm{~m}^{3}$. The hydraulic fracturing fluid intended for a stage would thus, be about $1,900 \mathrm{~m}^{3}$. This represents the maximum amount of fluid that could be released on the drill pad in a single spill. It would be contained within a volume of about $2,100 \mathrm{~m}^{3}$ with a safety factor of 1.1 .

Flowback may escape via a blowout during a single fracturing stage or leakage during the return period. The former volume could be no greater than the injected hydraulic fracturing fluid volume. Loss of hydraulic fracturing fluids in the formation are typically between 70 and $90 \%$ in the Marcellus Formation so the cumulative volume of flowback that reports to the wellhead from a $19,000 \mathrm{~m}^{3}$ injection would be about $600 \mathrm{~m}^{3}$ after three weeks. Flowback generally converts to produced water after about six weeks at which time a total of about $760 \mathrm{~m}^{3}$ of flowback would have arrived at the surface. In summary, while individual well conditions would differ in degree, a containment volume of $2,100 \mathrm{~m}^{3}$ would contain any realistic spill of either hydraulic fracturing fluid or flowback on the drill pad. Containment should consist of a diked and polymer-lined structure surrounding the wellhead.

2. Blowout Preventers. The above scenario allows for flowback to spill on the well pad for up to six weeks without exceeding the recommended containment capacity. In reality, any uncontrolled flowback would be brought under control almost immediately by installation of blowout preventers (BOPs). BOPs may be automatic, responding to drastic pressure changes, or manual. The latter can be engaged in the event the automatic BOP fails.

3. Wellbore Integrity. Flowback, as well as production gasses, may escape the wellbore as a result of casing failure or inadequate grouting. Pre-fracturing pressure testing of the wellbore to pressures in excess of the design strength of the wellbore will indicate whether adequate wellbore integrity has been achieved. It is recommended that the industry and regulatory agencies select a testing protocol and engineering standard to be applied to all future horizontal hydraulic fractured wells.

4. Impoundment Integrity. Hydraulic fracturing fluids and flowback are stored at the drill pad in tanks or impoundments. Poor design or construction can result in significant release of fluids to shallow groundwater. Impoundments must be lined with a polymer membrane. Guidelines for construction of hazardous liquid impoundments are available. They must be applied and enforced. In addition, a leakage detection system and monitoring plan is recommended. 
5. Disposal Plans. Plans for disposing of excess flowback should specify the type of disposal facility, the facility's name and location and the types and volumes of material to be disposed in each. Documentation of compliance with these conditions should be required as part of the horizontal gas well's permit.

\section{REFERENCES}

[1] Sampling and Analysis of Water Streams Associated with the Development of Marcellus Shale Gas Final Report; Thomas Hayes, Gas Technology Institute; for Marcellus Shale Coalition; December 2009.

[2] America's New Energy Future: The Unconventional Oil and Gas Revolution and the U.S. Economy Volume 1: National Economic Contributions; An IHS Report; October 2012 .

[3] Modern Shale Gas Development in the United States: A Primer; Ground Water Protection Council and ALL Consulting; Department of Energy Office of Fossil Energy DE-FG26-04NT15455; April 2009.

[4] Natural Gas Plays in the Marcellus Shale: Challenges and Potential Opportunities; David Kargbo, Ron Wilhelm and David Campbell; USEPA; Environmental Science \& Technology; Volume 44; Number 2010.

[5] Water Management Technologies Used by Marcellus Shale Gas Producers Final Report; John Veil, Argonne National Laboratory; Department of Energy Office of Fossil Energy FWP-49462; July 2010.

[6] Hydraulic Fracturing Considerations for Natural Gas Wells of the Marcellus Shale; Daniel Arthur, Brian Bohm and Mark Layne, ALL Consulting; The Ground Water Protection Council 2008 Annual Forum; 2008.

[7] Data Confirm Safety of Well Fracturing; Kevin Fisher, The American Oil \& Gas Reporter, www.aogr,com; July 2010.

[8] Chemicals Used in Hydraulic Fracturing; for U.S. House of Representatives Committee on Energy \& Commerce Minority Staff; April 2011.

[9] 'Environmentally Friendly' No Longer an Oxymoron to Oil and Gas; Tayvis Dunnahoe, Hydraulic Fracturing; www.EPmag.com; August 2012.

[10] Marcellus Shale Water Management Challenges in Pennsylvania; A.W. Gaudlip and L.O. Paugh, SPE, Range Resources Appalachia LLC, and T.D. Hayes, Gas Technology Institute, Society of Petroleum Engineers; SPE 119898; 2008 SPE Shale Gas Production Conference; November 2008.

[11] Radiological Survey Report: Marcellus Shale Drilling Cuttings; CoPhysics Corporation; April 2010.

[12] Marcellus Shale Potential Public Health Concerns Correspondence and Supplemental Reports: Supplemental Generic Environmental Impact Statement on the Oil \& Gas Regulatory Program - Well Permit Issuance for Horizontal Drilling and HighVolume Hydraulic Fracturing to Develop the Marcellus Shale and other Low-Permeability Gas Reservoirs; State of New York Department of Health; July 2009. 
[13] Incidental TENORM: A Guidance for State Solid Waste Managers; Association of State and Territorial Solid Waste Management Officials; April 2011.

[14] Naturally-Occurring Radioactive Materials (NORM); www.world-nuclear.org, August 2011.

[15] Radiation Sources in Natural Gas Well Activities; Gayle Nicoll, Occupational Health \& Safety Online; http://ohsonline.com/articles/.

[16] Evaluating the Environmental Implications of Hydraulic Fracturing in Shale Gas Reservoirs; J. Daniel Arthur, Brian Bohm, Bobbi Jo Coughlin and Mark Layne, ALL Consulting; 2008. 